\title{
CHINESE GARDENS AS A NATIVITY SCENE: MATTEO RIPA'S DESCRIPTION OF THE KANGXI EMPEROR'S CHANGCHUN GARDEN IN BEIJING
}

\begin{abstract}
A b stract. This article examines the description of the Changchun Garden in eighteenth-century Beijing, featured in Matteo Ripa's Storia della Fondazione della Congregazione e del Collegio de' Cinesi. An Italian missionary at the court of the Kangxi Emperor, Ripa had a chance to see and describe both the imperial parks and the intricacies of Chinese court etiquette. His detailed account, a precious source of information on the Changchun park, was accompanied by commentaries aimed at explaining the differences between "European" and "Chinese" aesthetic values. Therefore, this article offers a critical analysis of the account as a historical source, discussing the accuracy of some of the details described by Ripa, and subsequently provides an interpretation of the way he perceived Chinese parks, with an emphasis on his explanations of the "Chinese style" of laying out gardens. Finally, the last part of the article is dedicated to a comparison between a Neapolitan nativity scene (presepio) and the Qing gardens as drawn by Ripa at the end of his description, in order to demonstrate the "artificial naturalness" of Chinese parks.
\end{abstract}

Keywords: Chinese gardens; Qing gardens; European gardens; Matteo Ripa; chinoiseries; Changchun Yuan, Yuanming Yuan.

\section{INTRODUCTION}

In 1710, Matteo Ripa (Ma Guoxian 马国贤, 1682-1746), an Italian priest and missionary, arrived in China with a special mission to deliver a message to Charles Thomas Maillard de Tournon (1668-1710), a papal legate directly involved in the Chinese rites controversy that led to the ban imposed on Catholicism in the Qing empire, and inform him that he had been created

Albert KoziK, PhD candidate - University of Warsaw, Faculty of Culture and Arts, Institute of Art History, Principal Investigator for the research grant King of Engineers financed by the Polish Ministry of Education and Science; correspondence address - e-mail: a.kozik@uw.edu.pl; ORCID: https://orcid.org/0000-0002-6813-4393. 
cardinal (Liu 329). Although Tournon, imprisoned in Macao by the order of the Kangxi Emperor, died soon after hearing the news, Ripa himself made his way to Beijing, and eventually became a servant at the imperial court (Fatica and Zhuang 144-145). He stayed there until 1723 when he returned to Europe together with a set of engravings depicting the Mountain Resort in Chengde (Bishu shanzhuang 避暑山庄), Hebei, and a great deal of precious information on the Chinese court.

Matteo Ripa's stay in Beijing resulted in a series of detailed accounts and reports gathered in his Memoirs (Giornale) and the monumental Storia della fondazione della Congregazione e del Collegio de' Cinesi (both published posthumously), which shed light on his work as both a translator and artist in the service of the Kangxi Emperor as well as on his perception of the Chinese and their culture. The missionary returned to Europe just in time for the rising vogue for chinoiseries and shared his views with George I (16601727), king of Great Britain and Ireland, and probably made contact with other important figures of English political and social life (Gray 42).

It is the historical context of his stay in China that makes Ripa's narratives interesting, in particular because the beginning of the eighteenth century was marked by both an increasing popularity of the 'things Chinese' and a campaign aimed at renouncing the French theories of garden design in England (Brown 171-176), two intrinsically connected phenomena whereby European goûts where re-evaluated in favour of a new artistic sensitivity. In such a situation, stories brought to the continent by a servant of the imperial court himself were precious as never before.

The purpose of this article is to examine one of Matteo Ripa's accounts, namely his description of the Changchun Yuan 长春园, or the Garden of Everlasting Spring, one of the imperial gardens in Beijing founded at the beginning of the eighteenth century by the Kangxi Emperor. The missionary's account is a precious source of information on the park, and the problem of accuracy is of utmost importance in all similar narratives, widespread in Europe, yet often unreliable and verging on fantasy - if not fabrication (Lach 731-821). There was always a great deal of subjectivity and imagination involved in them, and many stories told by Ripa are no exception. He claimed, for instance, that his famous Thirty-Six Views of the Imperial Summer Palace at Jehol was executed based upon paintings commissioned specifically for him by the emperor himself. However, it has been proved that there exists a set of woodcuts made earlier by local Chinese artists and based upon the same set of paintings (Gray 42). While 
demonstrating that many of the details furnished by the missionary are in fact correct and accurate, the article will offer an analysis of Ripa's description of the Changchun Yuan as a model "Chinese" garden.

The account discussed in the article comes from the original Italian edition of Ripa's Storia della Fondazione della Congregazione e del Collegio de' Cinesi (first published 1832). Most recently, it has been translated into English by Bianca Maria Rinaldi (Ideas 83-90). There exists another English translation of several excerpts from the Storia della fondazione... made by Fortunato Prandi and published by John Murray already in 1844 , twelve years after the original Italian edition. Throughout this paper, Rinaldi's translation will be used with the addition of fragments omitted by the translator and supplemented by the author of this article.

\section{THE CHANGCHUN GARDEN}

Craig Clunas distinguished two different traditions of laying out parks and gardens in China, the first one being the so-called "fruitful garden," closely related to horticulture perceived as a process of managing orchards, collecting various species of plants, and consuming their fruits, and the other - the "aesthetic garden" so to speak - considered as a source of pleasure for people engaged in "aesthetic horticulture." The first type privileged productive and practical aspects of the garden and saw it as a repository of natural resources important from an economic point of view, whereas the other focused on the aesthetic qualities of gardens as landscape parks (Clunas 67). Even though the oldest tradition of laying out gardens was that in which the "fruitful" or "economic" side was the dominant one, over the years, and with the leading role assumed by the aristocracy in the process of the development of garden theory in China, the economic usefulness of gardens diminished, and their transformation marked a transition from practical and productive towards purely aesthetic aspects (Clunas 71).

This style of a fully "artificial" and economically unproductive garden became increasingly popular in the Ming and Qing periods, and the 1630s saw its codification in Ji Cheng's (1582-c.1642) Yuan Ye 园冶 (The Craft of Gardens; Zhou 429). In it, the author elaborated among other things on the principle of "borrowing scenery" (jie jing 借景), a practice whereby natural scenic spots were artificially recreated in private gardens, and described it as a “must-be in every park" (lin yuan zhi zui yao zhe 林园之最要者). Yuan Ye 
accounts for a vogue for such devices and provides much evidence in support of Clunas's theory that the fully "aesthetic" garden became the most fashionable genre of garden design in China by the times of the Qing dynasty.

The gardens of the Qing were natural heirs to the above-mentioned tradition, and the creators of the most famous foundations from the reign of the Kangxi Emperor - the Chengde Mountain Resort and the Old Summer Palace Gardens (Yuanming Yuan 圆明园), of which the Changchun Yuan was a part - indubitably followed in the footsteps of their prominent Ming predecessors (Xun 411). The Changchun Yuan abided by the rules prescribed by theoreticians of garden design - water bodies and mountains were chosen as dominant compositional motifs by which to organize the space, with hills and steep ranges enclosing the entire area, and pools, ponds, canals, or artificial lakes constituting the main elements of the design, in accordance with the "mountains surround and lakes embrace" (shan huan shui bao 山环水抱) principle that emphasized the subordinance of all the islands and hills to the all-encompassing rule of water (Xue, Zhou, Zhao, and Liu 173). Flooded with water, the whole area was then crisscrossed with islets, bridges, and hillocks upon which pavilions of different shapes and sizes were erected.

The artistic forms that Ripa had a chance to see in the Changchun Yuan were one of the stages in the development of Chinese landscape parks and represented the point of arrival of a very specific tradition. This is particularly important given the fact that one of the main reasons behind the missionary's decision to describe the Changchun Yuan for his readership was, as I will try to demonstrate, to stress the differences between the "European" and "Chinese" conventions of lying out gardens, an opposition that profoundly shaped the Western perception of China's parks in the eighteenth century.

\section{NATURE, ARTIFICIALITY, AND ORDER: THE FORM OF THE ACCOUNT}

Ripa's account of the Changchun Yuan spans only three pages in the Storia della fondazione..., but covers a wide range of topics, a description of the garden among them. What is specific about the missionary's narrative is the use of an ad-hoc Italian transcription of the Chinese language as opposed to a more conventional one developed earlier by Ripa's predecessors 
in China, in particular by Michele Ruggieri (1543-1607), Matteo Ricci (1552-1610) and, most notably, by Nicolas Trigault, whose manual Xi ru er $m u$ zi (西儒耳目资, Materials to Aid the Eyes and Ears of Western Literati) included the most authoritative rendition of the koiné guanhua (官话), or "Mandarin," at the time (Coblin 261-307). It was later improved by Francisco Varo (1627-1687), a Spanish Dominican friar, in his Arte de la lengua mandarina published in Canton in 1703.

Ripa, however, preferred to rely on a more intuitive transcription tailored for his implied Italian readership and based upon his mother tongue, the Neapolitan dialect of the Italian language, the reason why the name "Changchun Yuan" was rendered as "Ccin-Cciun-Juen" in his account. For instance, the doubled consonants "cc," which would be pronounced in Neapolitan as a geminated version of the voiceless palato-alveolar sibilant affricate $(/ \mathrm{t} f: /)$, were used to represent the Chinese aspirated voiceless retroflex affricate $/ \mathrm{ts} /$, and the letter ' $\mathrm{j}$ ' stands for the voiced palatal approximant $/ \mathrm{j} /$, according to the Neapolitan spelling conventions. The notation of the four tones was completely omitted, even though it had been well developed by the above-mentioned proto-sinologists and comprised already a set of diacritics to mark each tone (Furuya 1-25). The choice of transcription was clearly justified by the implied audience of Storia della fondazione-Ripa was interested in propagating the college he established in Naples and considered the text a source of popular rather than specialized knowledge. It was by answering to the demands of the readership that the author wanted to present his description of the Qing empire and its gardens.

The expectations of Ripa's readers are crucial to understanding how the author himself structured the narrative of Storia della fondazione. In it, he included a lengthy-yet-general description of the Changchun Garden, enumerating its countless elements, such as

a web of little mountains and hills, with pathways that in some places are broad and straight, in others tortuous, and that are interspersed with diverse paths that in some places are narrow and in others wider, flat and steep, straight and crooked, through mountains (some of which are connected by rough stone formations placed to look natural) and through valleys; thence over varied bridges on rivers and streams created with water brought in by art, and on these one goes from one side to the other, and also to some islets in the middle of the lakes... (Rinaldi 85-86)

Aside from describing the form of the garden, an important purpose of Ripa's account was to prove that the model "Chinese" and "Western" 
gardens differ profoundly in their approach to landscape design and that the Chinese "worked with art to imitate nature" rather than tried to supress nature by means of artificiality, a common practice in European "French" gardens patterned on the parks of Versailles:

This and all the other lordly villas that I saw are of the same taste, exactly the contrary of our European taste, since we here artfully attempt to distance ourselves from the natural, making the hills plain, draining out the dead waters of lakes, uprooting spontaneous trees, straightening roads, creating fountains with great effort, planting flowers in good order, and the like; the Chinese, on the other hand, work with art to imitate nature... (Rinaldi 84-85)

In fact, the narrative would not have been particularly interesting to the European public had it been deprived of the ambition to illustrate crucial differences between the two archetypical gardens, and the missionary was of course acutely aware of the great fascination with which the Westerners approached the "things Chinese."

Ripa's text mirrors the preconception that the "Chinese" garden is as close to nature as possible, and therefore visually disorderly, in contrast to the "European" garden which privileged harmony, symmetry, and visual consistency. For a long time, the Europeans had had a predilection for wellorganized and structured pathways within their gardens as well as for devising various sets of rules whereby gardens should be visited or navigated around. It was common to programme such paths by means of official instructions allowing for a perfect "sightseeing" experience and assuring that the visitors did not miss any opportunity to admire the beauty of the garden and its specific parts in the most proper order. Versailles, with dozens of fountains, sculptures, labyrinths, and alcoves as well as an astonishingly refined waterworks system propelled by the machinery at Marly (Ermenc 242-244), served as a model example of such "programmed" garden. There were numerous guides compiled in the seventeenth century by the order of Louis XIV (1638-1715), and there is one draft extant that bears traces of the king's own handwriting (Thacker 49).

This sense of order, projected on a garden space by means of rigid architectural rules and conceptual guidebooks, is entirely absent from Ripa's narrative - an important condition given his perception of "Chineseness." Order is, nevertheless, visible on a different level, as the account proves particularly detailed in the part dedicated to the imperial court etiquette: 
Its gates are always guarded by Tartar soldiers, because except for the Eunuchs, they permit entry to no one, except those to whom entry has been expressly conceded by the Emperor, and when they approach the gates in order to enter, [the guardians], not knowing them, ask: "Copu-pi?" which means "what is your name?" in the Tartar language. This noted on a tablet, they let them in. (Rinaldi 84)

Ripa's account is characterized by a great attention to detail, his accurate transcription of a conversation in the "Tartar" language being no exception.

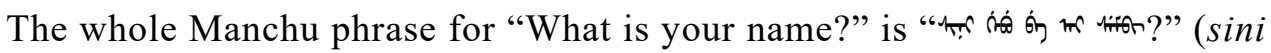
gebu be ai sembi) and was written by the missionary as "Copu-pi." The expression noted by the missionary is in itself a shortened version of the above

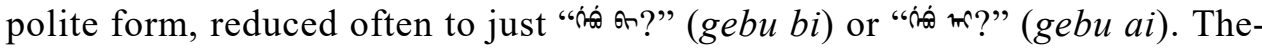
re is evidence that this is exactly the way this question would be asked in colloquial speech of the time, the prime example being the so-called Qing wen qi meng (清文启蒙, A Manchu Primer or, literally, An Explanation of the Qing language), a manual of the Manchu language written specifically for Chinese learners, first published in 1730. Another proof is the Suyu (俗语, Plain Talk), a phrasebook of colloquial Manchu for Chinese speakers compiled in the first half of the eighteenth century and treasured at the HarvardYenching Institute Library. The latter, in particular, provides an example of the conversation in which the phrase gebu ai was featured (Hanan 87).

The strong presence of Manchu guards in the parks was reflected in Ripa's account precisely because it was felt by all the visitors, and there is no doubt that the consequences of the Qing dynasty policies regarding the Eight Banners system were clearly visible even to outsiders, making them conscious of the Manchu domination over the empire. Indeed, numerous sources prove that the Kangxi Emperor reinforced the defences and guards of his palaces and that the Changchun Yuan was, much like the whole city of Beijing (Dray-Novey 885-992), kept under a particularly strict surveillance, with Manchu ("Tartar") soldiers constantly patrolling the territory. However, the strict rules of entering and leaving the garden presented in the account were seen by Ripa as a sign of "jealousy over the court ladies" ("la gelosia delle donne"):

\footnotetext{
${ }^{1}$ A part of Ripa's description was not translated by Rinaldi - it has been marked underlined above and translated by the author of this article.
} 
one has to get through another gate in front of which a few eunuchs are sitting with a large board covered with white paint on which they write the names of all those entering, and then wipe the names away with a piece of wet cloth, for which reason they know if at night, after a specific hour, they have all left the villa where none who is not a eunuch can spend a night. The same is done in Beijing, in the inner palace, and in the Tartar villa in the place called Jehol, and all that because of the jealousy over the court ladies who are kept within the inner palace in Beijing where the harem is located, and over all the others who live in the said villas. ${ }^{2}$

The whole excerpt may appear puzzling, since Ripa was inclined to explain what would be effectively called "safety measures" in modern parlance only with a reference to the supposed "emperor's jealousy." This preconception, although based on the old Chinese practice of isolating imperial concubines from the outside world in order to avoid any possible contacts with intruders, and therefore to protect the purity of the dynastic lineage, was partly faulty principally because there were several more important reasons to separate strangers from imperial residences at night. Chief among them was, indubitably, the sanctity of the Emperor himself, buttressed by millennia of Chinese political and religious thought which Manchu rulers were eager to adopt (Corradini 112-116).

As an imperial villa, the Changchun Yuan was, of course, of much less importance than the Forbidden City. And yet - together with the Mountain Resort - it was a summer residence of Qing emperors and their families for approximately six months every year (Barmé 115-116). The incentive to provide the parks with an effective protection of Manchu guards cannot be reduced to the mere presence of the harem, since the safety of the whole imperial family, with the emperor himself, was at stake here. Yet for the Europeans, the very existence of harems in some cultures seemed to possess a particular "oriental" charm and their descriptions were often made with a frisson of "exotic" excitement permeating Western culture (Said 190; Behdad 108-126; Grosrichard 5-16; Göçek 73). Given this context, it is little wonder that Ripa, although a Catholic priest, devoted a great deal of attention to the imperial harem and both the court ladies and eunuchs whom he encountered in China.

There is also another side to Ripa's focus on the strict security measures implemented at the entrance to the garden. It was mentioned earlier that if the architectural order, symmetry, and harmony were absent from the garden itself, they were superseded by a different sense of control and discipline,

\footnotetext{
${ }^{2}$ Not featured in Rinaldi's translation, translated by the author of this article.
} 
namely, by a system of harsh supervision - a proof of Chinese despotism which attracted much attention on the part of the Europeans in the eighteenth century. At that time, China was perceived in the West somewhat contradictorily as both a state of wise rulers who exercised their power by means of carefully adjusted policies and a domain of tyrants whose only will was to subdue their subjects with cruel laws and a sophisticated yet brutal punishment system (Zhan 93-111; Millar 716-737). Ripa's almost conventional mention of the "jealousy" lying at the root of the determination to keep a tight rein on visitors was but a part of a wider Western discourse portraying Chinese emperors as despots jealous of their power and authority.

THE WESTERN GAZE:

\section{THE CHINESE GARDEN AS A NATIVITY SCENE}

Ripa's perception of Chinese society in general and the Changchun Yuan in particular manifested principally in the last part of the narrative, in which an intriguing comparison was used to characterize the landscape of the imperial park:

To describe this complex in a few words, I will say that it has much of the taste of the good crèche scenes here in Naples made to represent the nativity of Our Lord naturally. And all the other [villas] of so many gentlemen are done in the same taste because this is the taste of the Chinese in their villas and their pleasure gardens. (Rinaldi 86-87)

For Ripa, the whole scene unfolding before the eyes of the visitor was similar to that of a Neapolitan presepio, or crèche, a traditional sculptural genre presenting Nativity in form of miniature figurines gathered against an elaborate landscape of hills, mountains, grottoes, and ruins, an artistic practice extremely popular in the eighteenth century (D'Aponte 49-51). There are several examples of works belonging to this current extant today, such as the one preserved at the Art Institute in Chicago (Reference Number 2013.59), which may prove salutary in reconstructing what Ripa meant by "good crèche scenes here in Naples."

The presepio from Chicago features over 200 miniatures representing people, animals, and various props such as food or beverages assembled in a chaotic space filled with houses, ruins, sculptures, and grottoes, all of which present the cityscape of eighteenth-century Naples rather than an 
imaginary historicized vision of Bethlehem. The diorama is thus a portrayal of the hustle and bustle of a contemporary city, with the conventional biblical scenes inscribed into a very modern - at least from an eighteenthcentury perspective - context. Depicted among this boisterous and festive crowd, the representation of the Holy Family seems to be lost in the general tumult. What strikes the beholder is an endless and disorderly parade of joyful characters, a mirthful commotion caused by almost theatrical characters (or "types," much like in commedia dell'arte plays) and, above all, a kaleidoscope of colours. The presepio is in itself a feast for the eyes of the five senses, sight is the one most engaged in the perception of the diorama. It is therefore a profoundly visual experience that Ripa had in mind while describing the Changchun Yuan.

In his account, the domain of order is that of the outer part of the garden where the guards exercise strict control over the visitors, whereas the inner sphere is reserved for "artificial naturalness," that is, nature imitated with artful contrivances. There, the space is in a state of visual disarray, constantly bombarding the visitors with an endless kaleidoscopic show of images, scenic spots, picturesque locations, and fancy architectural details. The scene is - to some extent at least - an imaginary picture of Chinese society, with women, merchants, and eunuchs presented against the backdrop of the "natural garden" in a way similar to the depictions of Neapolitan townsfolk in presepio. Any possible deeper political, societal, economic, and even cultural contexts are removed from the picture, either deliberately or unconsciously. The imperial parks of China, alongside the society of which they were a part, are reduced to mere visuality.

This particular instance of the Western gaze, i.e., reducing foreign - and especially "oriental" - cultures to but a show of pictures and sights, is of course far from being unusual in Europe. With the sense of sight privileged in similar accounts, it made part of a whole culture of looking at the Other. Suffice it to compare it to later narratives produced by nineteenth-century Europeans, who travelled to the 'Orient', and analysed exhaustively by Timothy Mitchel:

So here we are in Egypt (...) What can I say about it all? What can I write you? As yet I am scarcely over the initial bedazzlement (...) each detail reaches out to grip you; it pinches you; and the more you concentrate on it the less you grasp the whole. Then gradually all this becomes harmonious and the pieces fall into place of themselves, in accordance with the laws of perspective. But the first days, by God, it is such a bewildering chaos of colours... (21) 
The above quotation comes from Gustave Flaubert's (1821-1880) letter written in January 1850, more than a century later than Ripa's account. And yet, there are striking similarities between these two descriptions, even though they refer to different countries, different spaces, and different times. What permeates them is an impression of an overwhelming spectacle of colours and sights, at first virtually impossible to describe in an orderly manner, and then gradually fitting into one uniform - albeit not arranged systematically - picture. For Flaubert, this would be a picture of an unknown and exotic world in which the notions of time and distance are lost. For Ripa, this would be a familiar picture of a Neapolitan presepio, paradoxically organized according to the same principles that Flaubert attempted to discern in the cityscape of Cairo, namely, the principles of tumult and artificiality, the laws of world-as-picture.

Nevertheless, it would be impossible to claim that there is any particular sense of coloniality - and even racialization in the modern sense of the word (Demel 20-21) - involved in Ripa's account, since he was not a colonizer, and it was not until the nineteenth century that the colonial imbalance of powers dominated Sino-Western relationships. Creeping into the missionary's perception of China is, rather, a specific form of visual curiosity accompanied by deep-rooted preconceptions about how a garden should be perceived. The custom of arranging any park space according to strict rules of symmetry and mathematical correspondence was obviously imprinted into Ripa's perception of any garden space. This was precisely the reason for which comparisons with the "Western" garden were inevitable, at least as long as an eighteenth-century European traveller was involved.

Ripa's account is therefore a model example of such perception, although the "presepio analogy" drawn by the missionary at the end of his narrative managed to artfully link a sense of pictoriality with Ripa's own cultural upbringing. The idea that the garden was "spectacular" (in the etymological sense of the word, i.e., "pertaining to or characteristic of a spectacle," or even to "looking") found a rather unusual expression - China as a nativity scene may seem conceptually strange on the iconographical level, since there was nothing specifically "Christian" in the garden as Ripa saw it, but the powerful visual charge, of which the Neapolitan presepio became a vehicle, had a potential of conveying in full and summarizing for the reader the entirety of the missionary's experience. How to imagine China if one has never travelled to that land of wisdom and curiosity, shrouded in mystery and remote from both here and - so it seemed - now? How to imagine 
a garden that is by no means similar to the ones of Versailles or, suppose, of the Reggia di Caserta in the Kingdom of Naples?

To these questions Ripa had a simple answer, probably the most natural one for a Campanian priest; imagine the traditional Neapolitan presepio, and you will see the whole scene right in front of your eyes, vivid, even flamboyant. Superimposed upon this simple analogy was the missionary's Western gaze which prompted him to reduce what he saw to mere pageantry. No map was attached to the description, and it would have been useless, because Ripa's intentions had always been very remote from any form of "mapping" the Changchun Yuan. Put another way - in the eyes of the author, particular alleys were forever lost in the vibrant spectacle of the imperial garden, proving the theory of its "artificial naturalness" for his readership.

\section{BIBLIOGRAPHY}

\section{SOURCES}

Ji Cheng 计成, Yuan Ye 园冶. N.p., 1795, n. pag: Jie jing 借景.

Ripa, Matteo. Giornale 1705-1724, vols. 1-2. Istituto Universitario Orientale, 1991.

Ripa, Matteo. Storia della fondazione della Congregazione e del Collegio de' Cinesi sotto il titolo della Sacra Famiglia di G.C. scritta dallo stesso fondatore Matteo Ripa e de' viaggi da lui fatti, vols. 1-3. Napoli, Tipografia Manfredi, 1832.

Ripa, Matteo. "Storia della fondazione..." Ideas of Chinese Gardens: Western Accounts, 13001800, edited by B.M. Rinaldi. University of Pennsylvania Press, 2016, pp. 83-90.

Ripa, Matteo. Memoirs of Father Ripa, during Thirteen Years' Residence at the Court of Peking in the Service of the Emperor of China. With an Account of the Foundation of the College for the Education of Young Chinese at Naples Selected and Translated From the Italian by Fortunato Prandi. London, J. Murray, 1844.

Varo, Francisco. Arte de la lengua Mandarina. N.p., 1703.

\section{SeCONDARY Literature}

Barmé, Geremie. "The Garden of Perfect Brightness, Life in Ruins.” East Asian History, no. 11, 1996, pp. 111-158.

Behdad, Ali. "The Eroticized Orient: Images of the Harem in Montesquieu and His Precursors." Stanford French Review, vol. 2-3, no. 13, 1989, pp. 108-126.

Brown, Tony C. "Joseph Addison and the Pleasures of 'Sharawadgi'." ELH, vol. 74, no. 1, 2007, pp. 171-93.

Clunas, Craig. Fruitful Sites: Garden Culture in Ming Dynasty China. Duke University Press, 1996.

Corradini, Piero. "The Legitimization of the Qing Dynasty." Central Asiatic Journal, vol. 46, no. 1, 2002, pp. 112-127. 
D’Aponte, Mimi Gisolfi. "Presepi: A Neapolitan Christmas Ritual." Performing Arts Journal, vol. 2, no. 2, 1977, pp. 49-60.

Demel, Walter. "How the Chinese Became Yellow: A Contribution to the Early History of Race Theories." China in the German Enlightenment, edited by Battina Brandt and Daniel Purdy. Scholarly Publishing Division, 2016, pp. 20-59.

Dray-Novey, Alison. "Spatial Order and Police in Imperial Beijing." The Journal of Asian Studies, vol. 52, no. 4, 1993, pp. 885-922.

Ermenc, J. J. “The Machine of Marly.” The French Review, vol. 29, no. 3, 1956, pp. 242-244.

Fatica, Michele, and Yue Zhuang. "Copperplates Controversy: Matteo Ripa's Thirty-Six Views of Jehol and the Chinese Rites Controversy." Entangled Landscapes: Early Modern China and Europe, edited by Yue Zhuang and A.M. Riemenschitter. NUS Press, 2017, pp. 144-186.

Furuya Akihiro (古屋昭弘), “Mindai kanwa no isshiryō: Ricci, Ruggieri no Hinshu mondō shigi” (“明代官話の一資料：リッチ・ルッジエールの「賓主問答私擬」”[“The First Information about the Ming Guanhua: Ricci and Ruggieri's Baozhu wenda sini']. 東洋学報 Tōyō gakuhō (Toyo University Academic Journal), vol. 70, no. 3-4, 1989, pp. 1-25.

Göçek, Fatma Müge. East Encounters West: France and the Ottoman Empire in the Eighteenth Century. Oxford UP, 1987.

Gray, Basil. "Lord Burlington and Father Ripa's Chinese Engravings." The British Museum Quarterly, vol. 22, no. 1/2, 1960, pp. 40-43.

Grosrichard, Alain. Structure du sérail: La fiction du despotisme asiatique dans l'occident Classique. Seuil, 1979.

Hanan, Patrick, editor. Treasures of the Yenching: Seventy-Fifth Anniversary of the HarvardYenching Library [Exhibition Catalogue]. Chinese University Press, 2003.

Lach, Donald F., Asia in the Making of Europe, vol. 1. University of Chicago Press, 1965.

Liu, Yaxuan 刘亚轩. “Qing chu laihua chuanjiaoshi Ma Guoxian yu zhongxi meishu jiaoliu 清初 来华传教士马国贤与中西美术交流.” Neimenggu nongye daxue xuebao (shehui kexue ban) 内蒙古农业大学学报(社会科学版), vol. 10, no. 6, 2008, pp. 329-331.

Mitchell, Timothy. Colonising Egypt. University of California Press, 1988.

Millar, Ashley Eva. "Revisiting the Sinophilia/Sinophobia Dichotomy in the European Enlightenment through Adam Smith's Duties of Government." Asian Journal of Social Science, vol. 38, no. 5, 2010, pp. 716-737.

Pan Guxi 潘谷西, Zhongguo jianzhu shi 中国建筑史. Zhongguo Jianzhu Gongye Chubanshe 中 国建筑出版社, 2009.

Said, Edward. Orientalism. Pantheon Books, 1979.

Shi, Zhan. "L'Image de la Chine dans la pensée européenne du XVIII siècle : de l'apologie à la philosophie pratique." Annales historiques de la Révolution française, no. 247, 2007, pp. 93-111.

South, Coblin, W. "Notes on the Sound System of Late Ming Guanhua." Monumenta Serica, no. 45, 1997, pp. 261-307.

Thacker, Christopher. "La Manière De Montrer Les Jardins De Versailles, by Louis XIV and Others." Garden History, vol. 1, no. 1, 1972, pp. 49-69.

Shatzman Steinhardt, Nancy. Chinese Architecture: A History. Princeton University Press, 2019.

Wang, Xun 王逊, Zhongguo meishu shi 中国美术史. Renmin Meishu Chubanshe 人民美术出版 社, 2018. 
Wu, Ge 舞格. Qing wen qi meng 清文启蒙. N.p., 1730.

Xue, Xiaofei 薛晓飞, Zhou Hong 周虹, Zhao Jiuzhou 赵九洲, and Liu Min 刘敏. “Yuanming san yuan zhi zaoyuan yishu qiantan - Changchun yuan pian 圆明三园之造园艺术浅探一长春 园篇,” Laiyang nongxueyuan xuebao 莱阳农学院学报, vol. 17, no. 3, 2000, pp. 173-186.

Zhou, Weiquan 周维权, Zhongguo gudian yuanlin shi 中国古典园林史. Qinghua Daxue Chubanshe 清华大学出版社, 2008.

\section{CHINY JAKO BOŻONARODZENIOWA SZOPKA. RELACJA MATTEA RIPY Z WIZYTY W PEKIŃSKIM OGRODZIE CHANGCHUN UFUNDOWANYM PRZEZ CESARZA KANGXI}

\section{Streszczenie}

Celem niniejszego artykułu jest analiza opisu parku Changchun w osiemnastowiecznym Pekinie, zawartego w Storia della Fondazione della Congregazione e del Collegio de' Cinesi autorstwa Mattea Ripy. Jako włoski misjonarz na dworze cesarza Kangxi Ripa miał możliwość zobaczenia i opisania tak cesarskich parków, jak i zawiłości dworskiej etykiety. Jego relacja jest cennym źródłem na temat ogrodu Changchun, zawiera również wiele interesujących komentarzy mających na celu wyjaśnienie różnic między „,chińskimi” i „europejskimi” wartościami estetycznymi. W artykule przedstawiono zatem krytyczną analizę relacji Ripy jako źródła historycznego, skupiając się najpierw na wiarygodności części z opisanych przez autora szczegółów, a następnie na interpretacji sposobu, w jaki postrzegał on chińskie ogrody, kładąc nacisk na wyjaśnienie „chińskiego stylu” projektowania ogrodów. Szczególną wagę poświęcono wreszcie porównaniu chińskich ogrodów do neapolitańskich szopek bożonarodzeniowych, jakim posłużył się Ripa w swojej relacji, by uzmysłowić swoim czytelnikom ,sztuczną naturalność” modelowego ogrodu „chińskiego".

Słowa kluczowe: ogrody chińskie; ogrody europejskie; Matteo Ripa; chinoiseries; Changchun Yuan, Yuanming Yuan. 